says she 'looks like pink blancmange'; obviously no patient in that ward wanted pink blancmange with fish! Another time, some cold tongue and salad were offered for supper. As it was wheeled into the ward, a young medical student bent over, sniffed it very disdainfully and in a loud voice said 'What ghastly stuff'. Almost all the tongue and salad were refused.

If patients were all like experimental rats in cages, to be fed nutrients instead of food, if staff could be given packets of protein, fat and carbohydrates in the right proportion with the necessary dusting of minerals and vitamins, how simple hospital catering would be, but how tremendously boring without the human factor.

\title{
REFERENCES
}

King Edward's Hospital Fund for London (1945). Second Memorandum on Hospital Diets. London: G. Barber \& Son Ltd.

Ministry of Health (1950). Hospital Catering. Circ. Minist. Hlth, Lond., H.M.C., R.H.B., B.G. I8/50. Stevenson, J. A. F. \& Bensley, E. H. (I 947 ). Lancet, 252, 568.

\section{Some experiences in group nutrition}

By J. J. O'Dwyer, Principal Medical Adviser, Unilever Limited, Unilever House, London, E.C.4

I am very honoured to be asked to speak on such an occasion to such an audience. Twenty-two years spent in the Royal Army Medical Corps kept me in mind of the debt we owe to Alexis Soyer, whose centenary we celebrate, and I feel I must express my gratitude for the delightful, thoughtful and fascinating historical background given to us by Mr Le Gros Clark (1959) and Sir Zachary Cope (1959), doyen of medical historians.

It should be realized that I am not speaking as one skilled in the science of nutrition, but merely as a doctor who over the years has been brought face to face with gross problems of malnutrition, which even my untutored eyes would not miss. What follows are some reminisences which may, through knowledge of things seen in the past, help us to keep in perspective the problems of today.

My father was a dispensary doctor in the county of Tipperary and he made me aware of the nutritional problems of farm labourers' children between the years 1912 and 1914 . The area in which he worked, and in which we lived, was a land of rich, heavy soil, a country of numbers of small holdings and some large ones, mostly given over to dairy farming. Milk and butter were poor in quality, herds were of mixed breeds and tuberculosis-ridden, wages were low, profits poor. Every pint of cow's milk sold was important to a farmer, so accustomed by meagre times to extreme frugality that no cow's milk could be spared in many instances even for the farm labourer's small children-hence my father's anger with the times and his own people, the farmers included. Meat, butcher's meat, was only available to the comparatively well-off townsman or tenant or land-owning farmer; others were able 
once or even twice a week to get cheap bacon in those days--how far off it seems now -imported from Canada. So one saw in Ireland what I have seen since among that half of the world population still grossly underfed, the pot-bellied small children, the rickety ones, the unexplained stripped tongues and angular stomatitis.

This initial experience was made more real when I did my hospital work in Dublin and I suppose nothing could be more striking than the ill-clad, unshod, underfed children in the poorer districts of that city. The close relationship between lack of food and the many ills that I saw was really not brought home to me until I was taught preventive medicine on entering the Royal Army Medical Corps. Even on entry we began to learn, and through the years the learning continued and was constantly stimulated by lively hygiene teachers and workers.

Shortly after my initial training I was sent to India and worked in Calcutta for some years. Nobody of course could fail to see starvation in Calcutta itself, but I still have even more vivid memories of the really hungry countryside of east Bengal, seen on a march with troops to show the flag, which brought me into such hungry districts as were famine stricken in 1943-4. Here, to the most unseeing gaze, in the areas around Midnapore and Contai I saw real starvation: ribs sticking through thin skins, and such a lack of food that although the populace were originally frightened by the red faces clad in uniform, which they had not seen before in this rebellious area, gradually our march became a triumphal one, partly because of the kindness of the individual soldiers, officers, N.C.O's and men, and partly because of the food left over at each camp. Here was malnutrition in the grossest sense and one could well understand that any upset, small or large, that might occur either in the seasons or in the ability to import food into that region, would cause a famine, as it did in the dreadful war years. I feel here that it is necessary to emphasize that living in this country as we do, where we have a full, ample and varied diet, we should remember, as I said before, that one half of the world is hungry. This hunger seen in all its starkness was a tremendous shock to a young doctor, aged about 27 , and must shock anyone in this day and age who has ears to hear and eyes to see.

I returned to England in I933 and in the Royal Army Medical College the relationship between work, health and food was, in a year's postgraduate work, emphasized. I was fortunate enough to be made to learn something about public health and was taught hygiene lessons which stemmed from a tradition called into being by Edmund Alexander Parkes, the first professor of hygiene in the world, appointed to the Army Medical School at Chatham through the machinations of Florence Nightingale and Sydney Herbert.

For I year I was a soldier and not a doctor with the fruitful task of looking after 200 young recruits in our training centre at Crookham, near Aldershot. If one goes through the Army Hygiene Reports from 1865 to the present day one can see time and again what extraordinary tasks the Army were called upon to perform in order to render the undernourished fit, in order to make young persons able to do the tasks they were called upon to do. I still remember vividly, as a Company Commander responsible for these young men, that the average increase in weight which each squad had to show at the end of 3 months' training was $8 \mathrm{lb}$. per man or boy. As 
there was a large proportion of our population unemployed at that time, their sons came to us underweight and ill-nourished, and within the limitations of Army rations, and these were limited by the usual British desire to cut down military expenditure in peacetime, this increase in weight was achieved. I was, I am glad to say, made Messing Officer, so that I could watch this process carefully and closely. If a squad because it contained two large, overweight, young fellows, failed to show that high average increase in weight, the War Office Hygiene authorities came to visit the Depot and asked the reason why. It meant that the rations had to be used with care and attention. The best had to be made out of what was available, under conditions which we would now regard as somewhat unsatisfactory, as there was not the money available to improve them. The cooks were well trained, but the training of the people was such that any attempt to get them to eat undercooked meat, or vegetables that were not overcooked, met with severe resistance. I failed in that year to get the young men to eat any meat that wasn't thoroughly burned, or any vegetables that weren't soft and mushy. But these youngsters were good material; they were cheerful young men given a chance and they did put on their $8 \mathrm{lb}$. weight in the first 3 months of their service. It is a strange commentary on the nutritional state of a large part of our population as late as the year I934, doubtless well known to the Society through the work of many persons and groups, the Medical Research Council: Committee upon Quantitative Problems in Human Nutrition (1924) report on miners' feeding, and the vast amount of work done by members and former members of this Society.

However, what these young men wanted was lots of food, and good food. Breakfasts were: bread, margarine, tea and one solid dish, whether it was stewed heart, baked beans and bacon, or something of that kind. The midday meal was meat and two vegetables, with a pudding. For tea there was bread and margarine, tea-hot, strong and sweet, stewed in fact-and jam, or some other substance of that kind, and finally we were able to introduce for supper a good hot nourishing soup. When the young men saw that one was eating the latter oneself, they were willing to follow suit, but not until then. When one looks back on what Alexis Soyer did, one can well say that his interest in the feeding of the troops still bore fruit in 1934. One can praise the medical authorities who demanded a standard which called for that increase in weight, and one wonders in retrospect how it was achieved with the scanty meals available in the days when economy in the Army was the watchword, and any money spent on the Services was deemed to be wasteful, and as for modern equipment, that was almost out of the question.

Then came the war, and I found myself in Malaya. We did not go to war in the Far East until the end of 194I, but before that there were some interesting contrasts in feeding, based on the nationalistic tendencies of all of us. For example, the ration of meat for Australian troops was $18 \mathrm{oz} . / \mathrm{man} / \mathrm{day}$; the ration for the British troops was ro oz. When our ration came down to 8 oz. the Australian ration came down to 12 oz. But what happened to our Indian, Chinese and Malayan colleagues? We were then beginning to appreciate the importance of giving them enough protein, and I suppose the high protein needs of the Indian troops struck one very forcibly, 
but of that more anon. In Malaya at least at that time there was enough good food to give to the soldier but it was another story for a large proportion of the civil population.

At that time I was brought into contact with the Institute for Medical Research at Kuala Lumpur and I received such instructions as I was free to take advantage of, giving me some understanding of the nutritional problems in the Far East. It came from the members of the Institute, the health officers of the government all over the country. I like to recall the names of some of these men, who did so much to integrate medical and civil thinking on problems of nutrition in that part of the world and taught me lessons which were to stand me in good stead throughout the years to come. Such were Dr William Scharff, Dr John Stewart, now with WHO, Dr Tom Wilson, Dr Robert Burgess, but many others assisted in my education, so that when I fled from Malaya and Java and got to Ceylon I had at least some conception of my duties as Health Officer to the Army and in regard to the feeding of the troops.

In Ceylon we had East African troops who were willing to eat rations of any kind, provided they were given not coarse maize meal but the finer meal which they themselves had been brought up on, but they accepted any supplements to the diet which came from India, or from Europe, and they became in the course of time, fit well-nourished men, able to stand up to severe testing and endurance which they had to bear later on in the jungles of Burma. We had Indian troops, Sikhs, other Hindus and Moslems whose diet was controlled by their religion and we had a real task to give them enough protein that they would accept. I do not think we ever succeeded in this task at that time, but we tried very hard.

I had one shattering experience during those days in the Chagos Archipelago, where there was an island occupied by troops, white and coloured, from Mauritius. They seemed to have got lost, but they were put under the control of Ceylon Army Command on I June I942. We got a cable to say that there was an outbreak of beriberi amongst them. The General Commanding Ceylon, General Sir Henry Pownall, and his excellent Major General in charge of Administration, General Snelling, immediately empowered me to gather from all over Ceylon whether from shops, from the public, or from Army stores, all the substances that I could get containing the $B$ group of vitamins. The next day I was flown to that island in a Catalina from a Dutch squadron, with $500 \mathrm{lb}$. of precious foodstuffs for this lost little community. Unfortunately, I was told that I was not to stay and follow up the work being done, there was too much to be done elsewhere, but at least the outbreak of beriberi ceased and the troops were subsequently well cared for. There was in fact only one death, from a heart attack caused by beriberi, so the other men were saved, but I saw in that small community all the classic and some non-classic signs of that illness, and I came back much wiser than when I left.

It was then my lot to go to the North of India to a training command where I saw the undernourished volunteers gathered into the Army units for training. As I travelled around, it was impossible to find whole Indian units which did not show some of the grosser signs of malnutrition. As one walked along the ranks of 500-1000 men and looked again at the stripped tongues and angular stomatitis, at the signs of 
anaemia in men who were sturdy, strong and active, one's heart sank because the task of getting enough protein to them seemed almost impossible and when they went to the Burma front they faded away in illness, so that our rate of casualties from sickness, malaria and malnutrition gradually rose more quickly than we could fly in reinforcements. There was just not enough food to go round. We wanted tinned milk in sufficient quantities to give every one of these men, who were working under the most severe conditions, one small can of milk daily, but we were informed that we had asked for more than the world's supply. Vividly do I remember my experiences of that time.

And then came the famine, to which I had to close my eyes. There was a war, there were ill-fed troops who were fighting and it was my task to help in some little way to keep them in the field. In 1944 came the realization in Europe that perhaps the Far East was of sufficient importance to warrant food being sent to it, and so the needs for milk, which were greater than the world's supply, began to be satisfied. By this time we were so scared that we had called for nutritional research teams, one from the U.K. one from Canada, to have a look at our ghastly problems. But men of this kind cannot be whistled up in a day, nor can teams be got together, equipped and taken out by sea or air in the twinkling of an eye, or taken away from jobs which were themselves very important. They did arrive, and much valuable work was done. Perhaps for an assessment of the situation, it would be worth recalling an article by J. N. Morris (1945) in the Lancet and numerous subsequent articles from 1947 to 1949 that gave a picture of some of the problems of those times. Such men as John Merryfield Walker, Robert Kark, now of Chicago, and others put all their brains and their ingenuity at our disposal and with the guidance of persons like Angus Thomson, now of Aberdeen, and Dr W. R. Aykroyd, once a fellow student of mine at Trinity College, Dublin, then head of the Nutrition Institute at Coonoor, and now head of the Nutrition Division of FAO, we were enabled to put into practice many of the remedies and aids with which we finally overcame our most difficult problems, but of course what mattered was getting the food, the milk, the meat, the fish. Perhaps most interesting, an impression of trends that are left over from those dreadful days, is the difference that food made to people's reaction to disease. Diarrhoea and dysentery were a cause of severe and most crippling illness and sometimes of death. It is true that our hygiene measures improved with the improving war conditions, but all of us felt quite certain that adequate feeding had much to do with the rapid disappearance of signs of severe illness, long convalescence and semipermanent unfitness which afflicted so many patients in 1943 and the first half of 1944, but by early 1945 these conditions had disappeared. It is true that mepacrine cut down malaria, but it is equally true that adequate feeding created a resistance to the disease not known in the earlier days.

We were worried about two other matters. One was the vitamin $\mathrm{C}$ content of the ration, but we forgot that men brought up in the country, notably Indian troops, found their own vitamin $\mathrm{C}$ food often in the hedgerows and in the fields. We were worried about the vitamin A content of our diet because it did not come up to the set standards, but our two nutritional teams could find no signs or symptoms of vitamin 18 (1) 3 
A lack in the course of their investigations. These of course were stark, dramatic, days and anyone who lived through them will never be able to forget them. It is sad to think that in each war, despite the best endeavours of those who know the answers, it seems impossible to avoid near catastrophe from disease and lack of food among the troops who fight our battles for us. The contrast when I came back to England in 1946 was extremely startling.

I left England in January I939, having spent 3 years on Merseyside in an area of gross unemployment, and I came back in 1946 to see children in our poorer streets, who seemed to me to be a miracle of fitness, rosiness and healthfulness. The contrast between 1939 and 1946 was to me almost miraculous, and a wonderful tribute to the rationing during the war period. Of course this did not apply only to the children, it applied also to many adults. The well off were slimmer and fitter because they could not get too much food, and others who had little before, had learned new methods of eating. It is true that fruit and vegetables were scarce, but their very scarcity seemed to make them more popular than they had been before I left. I suppose canned foods must have been scarce, but the desire for fresh foods in a part of the population that had never thought it could buy them in prewar days seemed to be greater than I had ever known it. But what I have said about Great Britain is really tautological, the state of nutrition in the years I have spoken of is so admirably explained by Miss Hollingsworth's chapter in that wonderful book The Englishman's Food by the late Sir Jack Drummond and Anne Wilbraham (Drummond \& Wilbraham, 1957).

After all this, it is difficult for me to discuss, in what I consider these days of plenty, the problem of feeding in factories, in a well-fed population. The gross problems have been to me so gross that I have grown somewhat impatient of minutiae. I listen to my learned colleagues on the subject of standards of vitamins and the like, and I am sure that they are most important for research work and for an understanding of fundamentals, but when I talk to our own people, I am more concerned with cleanliness, with avoidance of food poisoning, with providing the proper conditions in which food can be cooked and served, than I am about the problem of whether we eat enough vitamin C-containing food, whether we serve too much or too little butter or margarine, or whether the protein content of our diet adds up to the maximum or not. We have at least reached the stage in this country where most of us know, even if we do not take it, what is good for us, but conditions of public feeding are often deplorable. They are no worse in factories than they are in restaurants, hotels, eating houses, they are often much better, but continued co-operation between caterers, doctors and others in educating men and women at work to continue to eat the well-balanced diet that we had to eat during the war is most necessary, as are vigorous efforts to raise hygiene standards in all our canteens. Variations in these standards have often shocked me and due recognition of the important role of caterers and catering advisers is a beginning. Our experience will be more necessary than ever when our young male population is not exposed to the hardening and physical build-up of 2 years' national service, of which one virtue is to teach them to value good food. The nation's children are fitter physically in these 
days than they have ever been and it is our task to help to keep them fit through adolescence to adulthood, by example, teaching, and setting standards of meal content, cleanliness and good handling to stand them in good stead through life.

\section{REFERENCES}

Clark, F. Le G. (1959). Proc. Nutr. Soc. 18, I.

Cope, Z. (1959). Proc. Nutr. Soc, 18, 6.

Drummond, J. C. \& Wilbraham, A. (1957). The Englishman's Food, and ed. London: Jonathan Cape. Medical Research Council: Committee upon Quantitative Problems in Human Nutrition (1924). Spec. Rep. Ser. med. Res. Coun., Lond., no. 87.

Morris, J. N. (1945). Lancet, 248, 743 .

\section{Human problems in Service feeding}

By J. A. Mullington, Armed Services Supplies Branch, Ministry of Agriculture, Fisheries and Food, Dean Bradley House, Horseferry Road, London, S.W.I

In introducing this talk, I must emphasize that I have no scientific or nutritional background, and that my experience with the feeding of servicemen has been limited to that of a provisioner.

I would also like to say how grateful I am for the advice and assistance I have received at all times from those concerned with the scientific and nutritional aspects of Service feeding.

The feeding of servicemen seems to me to give rise to more problems than any other group feeding, inasmuch as we have to remember:

(a) The services consist largely of young adults with healthy and hearty appetites, which are further enhanced by the open air life most lead.

(b) Men come from all walks of life and from all areas. We have therefore to deal with local and even national eating habits.

(c) We must maintain a ration that will keep the men fit and ready to undertake operations in any part of the world at short notice and under very adverse conditions.

(d) Overseas we must make the utmost use of suitable local items in order to conserve shipping. We must therefore be prepared to vary the ration to meet local conditions.

(e) When operations are in progress or until fresh supplies can be built up the serviceman must exist on tinned foods.

(f) Cooking facilities in the field are of necessity somewhat primitive and restricted and very often meals can only be provided as the tactical situation allows.

(g) For various reasons we must provide a large portion of the ration in kind, or lay down definite limits within which it will be provided, in order to ensure that the diet does its necessary work of keeping the men in fighting condition.

(h) As a public service, we are subjected to stringent financial supervision. We have therefore to keep cost continuously in mind, and the Services' food budget is costly. 